\title{
Effects of Fucus vesiculosus covering intertidal mussel beds in the Wadden Sea
}

\author{
A. Albrecht \& K. Reise \\ Biologische Anstalt Helgoland, Wattenmeerstation Sylt; D-25992 List, \\ Federal Republic of Germany
}

\begin{abstract}
The brown alga Fucus vesiculosus forma mytili (Nienburg) Nienhuis covered about $70 \%$ of mussel bed (Mytilus edulis) surface area in the lower intertidal zone of Königshafen, a sheltered sandy bay near the island of Sylt in the North Sea. Mean biomass in dense patches was $584 \mathrm{~g}$ ash-free dry weight $\mathrm{m}^{-2}$ in summer. On experimental mussel beds, fucoid cover enhanced mud accumulation and decreased mussel density. The position of mussels underneath algal canopy was mainly endobenthic ( $87 \%$ of mussels with $>1 / 3$ of shell sunk into mud). In the absence of fucoids, mussels generated epibenthic garlands ( $81 \%$ of mussels with $<1 / 3$ of shell buried in mud). Mussel density underneath fucoid cover was 40 to $73 \%$ of mussel density without algae. On natural beds, barnacles (Balanidae), periwinkles (Littorina littorea) and crabs (particularly juveniles of Carcinus maenas) were significantly less abundant in the presence of fucoids, presumably because most of the mussels were covered with sediment, whereas in the absence of fucoids, epibenthic mussel clumps provided substratum as well as interstitial hiding places. The endobenthic macrofauna showed little difference between covered and uncovered mussel beds. On the other hand, grazing herbivores the flat periwinkle Littorina mariae, the isopod Jaera albifrons and the amphipods Gammarus spp. were more abundant at equivalent sites with fucoid cover. The patchy growth of Fucus vesiculosus on mussel beds in the intertidal Wadden Sea affects mussels and their epibionts negatively, but supports various herbivores and increases overall benthic diversity.
\end{abstract}

\section{INTRODUCTION}

The mussel Mytilus edulis L. generates drifting clumps and biogenic reefs in the Wadden Sea. These mussel beds are abundant in the lower tidal zone and subtidally (Verwey, 1954; Riesen \& Reise, 1982; Dankers \& Koelemaij, 1989; Obert \& Michaelis, 1991), constituting ecological elite structures in terms of the high number of associated species (Dittmann, 1990), biomass and secondary production (Asmus, 1987), foraging site for birds (Swennen et al., 1989; Zwarts, 1983), remineralization, and oxygen consumption (Dame \& Dankers, 1988; Asmus et al., 1990).

The phenomenon of Fucus vesiculosus growing on intertidal mussel beds was first described by Nienburg $(1925,1927)$ for the Königshafen Bay of Sylt. Since then, the cooccurrence of $F$. vesiculosus and mussel aggregations (large beds or drifting clusters) on soft sediments has been reported by several authors from different locations along the North Sea coast (Wohlenberg, 1937; Nienhuis, 1970; van den Hoek et al., 1979). In this association, F. vesiculosus lacks a holdfast and gas vesicles, and is attached to the substratum by byssus threads of the mussels. Reproduction is vegetative by means of fractioned thalli. Due to mud accumulation in the mussel bed, the algae are gradually 
buried in sediment whilst simultaneously growing upwards in the water column. Nienburg $(1925,1927)$ described the reciprocal effect of mussels and fucoids on each other as beneficial for both parties. He believed that $F$. vesiculosus prevented the mussels from sinking into the mud, whereas mussels enabled steady growth of the alga by holding it firm with their byssus threads.

In the present study, investigations about the possible effects of fucoid cover on mussels are extended to the associated macrofauna of mussel beds. The macroalgae represent an additional physical and biological structure in the mussel bed community. This structure could function as food for herbivores and a habitat for epifauna (Nicotri, 1980), as substrate for epiphytes (Kangas et al., 1982) or as shelter against physical stress and predation (Dean \& Connell, 1987), thus increasing overall habitat complexity.

Results were obtained by parallel sampling of covered and uncovered beds in the tidal zone of Königshafen near Sylt. The hypothesis that patches of $F$. vesiculosus significantly alter siltation and the composition of the species assemblage, was tested experimentally.

\section{MATERIAL AND METHODS}

\section{Study site}

Investigations were carried out in "Königshafen", the same shallow tidal bay near the island of Sylt, North Sea, where Nienburg (1925) first studied the Fucus-Mytilus association. The distribution and size of mussel beds in the area have been subject to great variation since the early reports from the beginning of the century. Such fluctuations were caused by severe winters (Ziegelmeier, 1964, 1970) and presumably eutrophication (Reise et al., 1989).

Two locations in the bay which are characterized by different physical properties were chosen for this study. The "Oddewatt" at the eastern opening of the bay represents an exposed site with mussel beds extending along the low water line; the "Möwenbergwatt" is located in the central part of Königshafen and is thus more sheltered, with mussel beds being situated slightly further upshore. Both locations are sandy, but the Oddewatt is characterized by a higher portion of coarse $(0.36-0.6 \mathrm{~mm})$ and a lower portion of fine (0.09-0.15 mm) sediment (Austen, 1992).

\section{Algal biomass}

Thalli of Fucus vesiculosus were clipped at the sediment surface from patches with dense growth ( $100 \%$ surface cover; visual estimation) on mussel beds in Möwenbergwatt. Twenty replicate samples of $0.25 \mathrm{~m}^{2}$ were taken between May and June 1990. In the laboratory, the thalli were washed with seawater, blotted and weighed (fresh weight), and then dried for three days at $80^{\circ} \mathrm{C}$ (dry weight). 6 samples, each weighing $25 \mathrm{~g}$ (dry weight), were combusted for $5 \mathrm{~h}$ at $520^{\circ} \mathrm{C}$ to determine the organic content as ash-free dry weight.

\section{Siltation experiment}

A field experiment was designed to test whether Fucus vesiculosus cover enhances mud accumulation on mussel beds, and whether this affects mussel density. From mussel 
beds in Möwenbergwatt - which display a mosaic of fucoid cover - clumps of mussels with and without attached algae were removed with a shovel. They were arranged in beds of approximately $\mathrm{lm}^{2}$, four with and three without algae, at a distance of about $2 \mathrm{~m}$ from each other and situated in the direct vicinity of the natural beds. Clumps of mussels were placed together, with an adhering layer of mud, upon circular sheets of plastic foil which, subsequently, served as a reference to measure the height of sediment accumulation. This was determined by probing a ruler 10 times into the mud of the central area $\left(0.3 \mathrm{~m}^{2}\right)$ of each mussel bed. The initial density of mussels ( $>10 \mathrm{~mm}$ shell length) was arranged into 200 individuals on $1000 \mathrm{~cm}^{2}$ with an approximate error of \pm 50 . Mussel spat was not considered in the counts, because it was insignificant compared to the number of individuals.

The vertical position of mussels in the sediment was categorized as either infaunal $(>2 / 3$ of shell sunk into the mud), semi-epifaunal $(2 / 3$ to $1 / 3)$ or epifaunal $(<1 / 3$ of shell buried in mud).

The experiment was started on July 3rd 1991 and terminated on July 18th 1992. Throughout the experiment the drift algae encountered were removed from the three beds designed to be free of fucoids. After July 1992, the experimental beds were left unattended. In November 1992, these beds were completely covered by $F$. vesiculosus again.

\section{Comparison of macrofauna}

At both locations - Oddewatt and Möwenbergwatt - 12 replicate samples each were taken from mussel bed patches covered with Fucus vesiculosus and from uncovered patches during June to August 1990. Sampling procedure was selective, in that samples were taken in pairs of two from directly adjacent areas of the same mussel bed that was only partly algae-covered. Thus, fucoid growth was the only obvious parameter differentiating the two plots.

A box corer of $500 \mathrm{~cm}^{2}$ surface area was used to take samples down to a depth of $15 \mathrm{~cm}$, below which no living macrofauna occurred. If present, algae were cut off the surface and treated separately: any adhering epifauna was washed off and retained in a sieve ( $500 \mu \mathrm{m}$ mesh size) to be identified and counted. The sediment portion of the sample was washed and sieved $(500 \mu \mathrm{m})$ and the residues from the sieve transferred into sorting dishes from which animals were extracted alive. All taxa, except oligochaetes and gammarids, were identified to species level using a stereo microscope. Heavy recruitment of Carcinus maenas and Nereis diversicolor occurred during the sampling period; therefore these species were roughly grouped into size classes.

\section{Statistics}

Differences in faunal densities (and in vertical position of Mytilus individuals) between algae-covered and uncovered mussel aggregations were tested with the nonparametric U-test of Wilcoxon, Mann \& Whitney (Sachs, 1984). Differences were considered significant at different levels and marked by asterisks in the following fashion:

$$
\text { * } 0.05 \geq p>0.02, * * 0.02 \geq p>0.002, * * 0.002 \geq p
$$

Usually, abundances are given as means $(\overline{\mathrm{x}})$ and standard deviations (SD). For comparison of macrofaunal assemblages, two indices were calculated: (a) Shannon- 
Wiener-Index $\mathrm{H}=-\Sigma \mathrm{p}_{\mathrm{i}} \cdot \ln \mathrm{p}_{\mathrm{i}}$, with $\mathrm{p}_{\mathrm{i}}$ being the portion of a species' $\left(\mathrm{n}_{\mathrm{i}}\right)$ number of individuals based on the total number of individuals $(N): p_{i}=n_{i} / N_{i}(b)$ Evenness e $=H / \ln S$, with $S$ being the total number of species.

\section{RESULTS}

\section{Algal cover}

Patches within mussel beds covered entirely by Fucus vesiculosus had a biomass of $4811 \pm 909 \mathrm{~g}$ fresh weight or $1050 \pm 187 \mathrm{~g}$ dry weight $\mathrm{m}^{-2}(\mathrm{n}=20)$, corresponding to $584 \pm 104 \mathrm{~g}$ ash-free dry weight $\mathrm{m}^{-2}$ in May to June 1990 . Fucoid surface cover of mussel beds in 1990 was estimated at $60 \%$ in Oddewatt and $70 \%$ in Möwenbergwatt. The following year in June, surface cover in the mussel bed areas reached 95 and $55 \%$, respectively. With $70 \%$ cover as an overall mean, fucoid biomass on mussel beds in Königshafen was approximately $400 \mathrm{~g}$ ash-free dry weight $\mathrm{m}^{-2}$ in summer.

\section{Siltation experiment}

Within 5 days after setting-up the experimental mussel beds, the distribution of mussels had changed from the initial even arrangement. During this time, weather conditions had been constantly calm. In the absence of fucoid cover, mussels aggregated into epibenthic garlands. Thick diatom growth was visible on the mud surface in the interspaces. In the presence of fucoids, mussels formed a continuous monolayer, with most individuals buried in mud by about two-thirds of their shell length. When probing the mud depth after 4 weeks in August, a smell of hydrogen sulfide was apparent.

In the course of the experiment all mussel beds became larger. Initially, the mean size was $1.1 \mathrm{~m}^{2}$. Six months later the mean size was $1.6 \mathrm{~m}^{2}$, with no significant difference between treatments. However, mussel beds without fucoid cover had twice the mussel density of beds with algae. Mean density of mussels was $119 \pm 12$ and $61 \pm 21$, respectively, (July, 1992) on $1000 \mathrm{~cm}^{2}$ in the centre of beds. Taking the areal increase of each mussel bed into account, mussel numbers had decreased by the end of the experiment (after 1 year) by $15 \pm 10 \%$ without fucoid cover and by $54 \pm 18 \%$ with fucoid cover. This difference was significant at the $5 \%$-level (U-test).

Experimental mussel beds covered by Fucus vesiculosus accumulated more sediment than the bare beds (Fig. 1). Initially, the height of mud was $95 \pm 6 \mathrm{~mm}$. With algal cover, sediment height increased until December to $123 \pm 19 \mathrm{~mm}$, decreasing thereafter to $84 \pm 10 \mathrm{~mm}$ in July 1992. Intermittently, the net gain of sediment at one bed was up to $47 \mathrm{~mm}$. Without algal cover, the height of mud decreased to $41 \pm 10 \mathrm{~mm}$ in December and further to $22 \pm 23 \mathrm{~mm}$ in July 1992 .

\section{Vertical position of mussels}

In the experiment, it was already observed that mussels underneath fucoid cover were positioned primarily in the mud, while in the absence of Fucus vesiculosus most mussels were positioned in clumps above the mud surface. The relative position of mussels to the sediment surface was recorded in replicate samples taken from mussel 


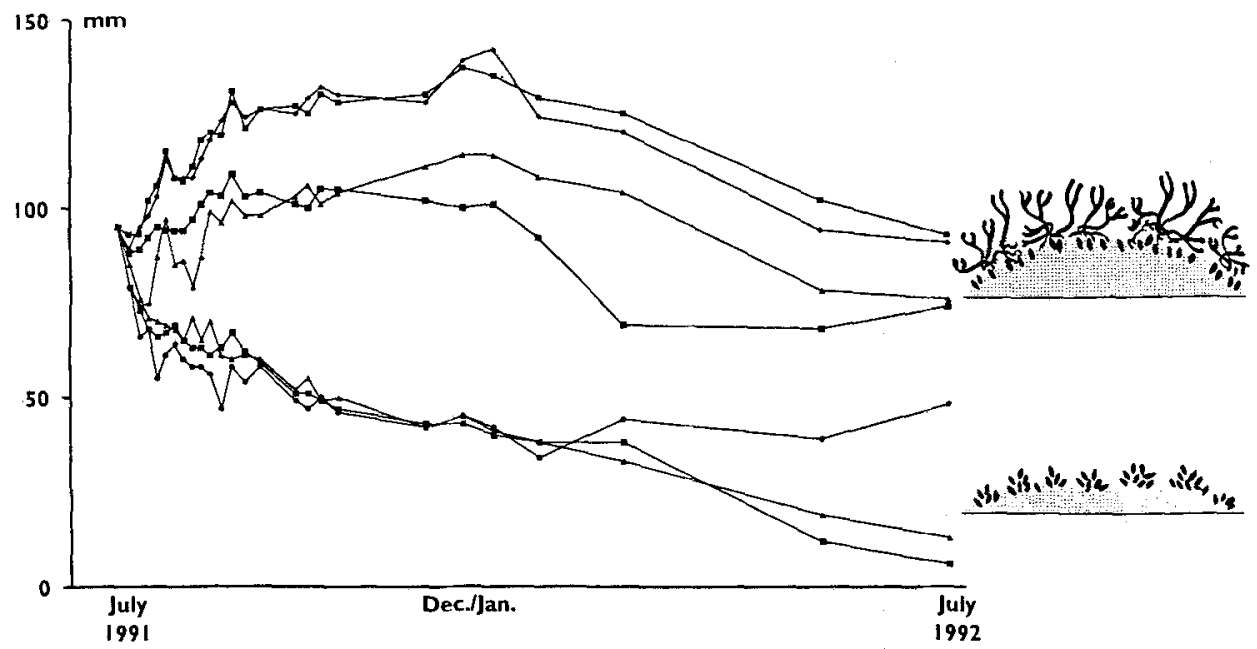

Fig. 1. Height of mud surface in experimental mussel beds, 4 beds with and 3 without fucoid cover, measured at irregular intervals between July 1991 and July 1992. Mean values of 10 measurements each are plotted per site and date (average standard deviation $9.5 \mathrm{~mm}$ ). Initial height varied between 84 and $105 \mathrm{~mm}$ and was standardized to the mean of $95 \mathrm{~mm}$ to facilitate comparison

beds in Möwenbergwatt that comprised a mosaic of bare patches and patches with fucoid cover (Table 1). Underneath fucoid cover, the density of mussels was only $40 \%$ of the density without algae, and most mussels had sunk into the mud. In the presence of fucoids, $87 \%$ of mussels $(>10 \mathrm{~mm}$ ) were buried in mud with $>1 / 3$ of their shell length (endobenthic growth). In the absence of fucoids, $81 \%$ of mussels were buried in mud with $<1 / 3$ of shell length, most of them being clumped together in epibenthic garlands, often 2 to 3 mussel lengths in height.

\section{Fauna of mussel beds with/without fucoid cover}

At the two investigated sites, paired samples from patches of mussel beds covered with dense growth of Fucus vesiculosus and patches free of fucoid algae revealed striking differences in epifaunal species composition (Table 2), whereas there were no

Table 1. Abundance and position of Mytilus edulis (>10 mm shell length) in patches with ( $\mathrm{n}=$ 6 sites) and without $(n=6)$ Fucus vesiculosus in Königshafen, June 1991. The position is recorded as the percentage of individuals in infaunal position ( $>2 / 3$ of shell length sunk into the mud), semiepifaunal $(2 / 3$ to $1 / 3)$ and epifaunal $(<1 / 3)$. Asterisks assign significance level after U-test

\begin{tabular}{|lccc|}
\hline Mussels & $\begin{array}{c}\text { With Fucus } \\
(\overline{\mathrm{x}} \pm \mathrm{SD})\end{array}$ & $\begin{array}{c}\text { Without Fucus } \\
(\overline{\mathrm{x}} \pm \mathrm{SD})\end{array}$ & Significance \\
\hline Ind./400 $\mathrm{cm}^{2}$ & $49 \pm 16$ & $122 \pm 24$ & $\ldots$ \\
$\%$ infaunal & $19 \pm 15$ & $3 \pm 7$ & $\ldots$ \\
$\%$ semi-epifaunal & $68 \pm 19$ & $17 \pm 21$ & $\ldots$ \\
$\%$ epifaunal & $13 \pm 13$ & $81 \pm 27$ & $\ldots$ \\
\hline
\end{tabular}




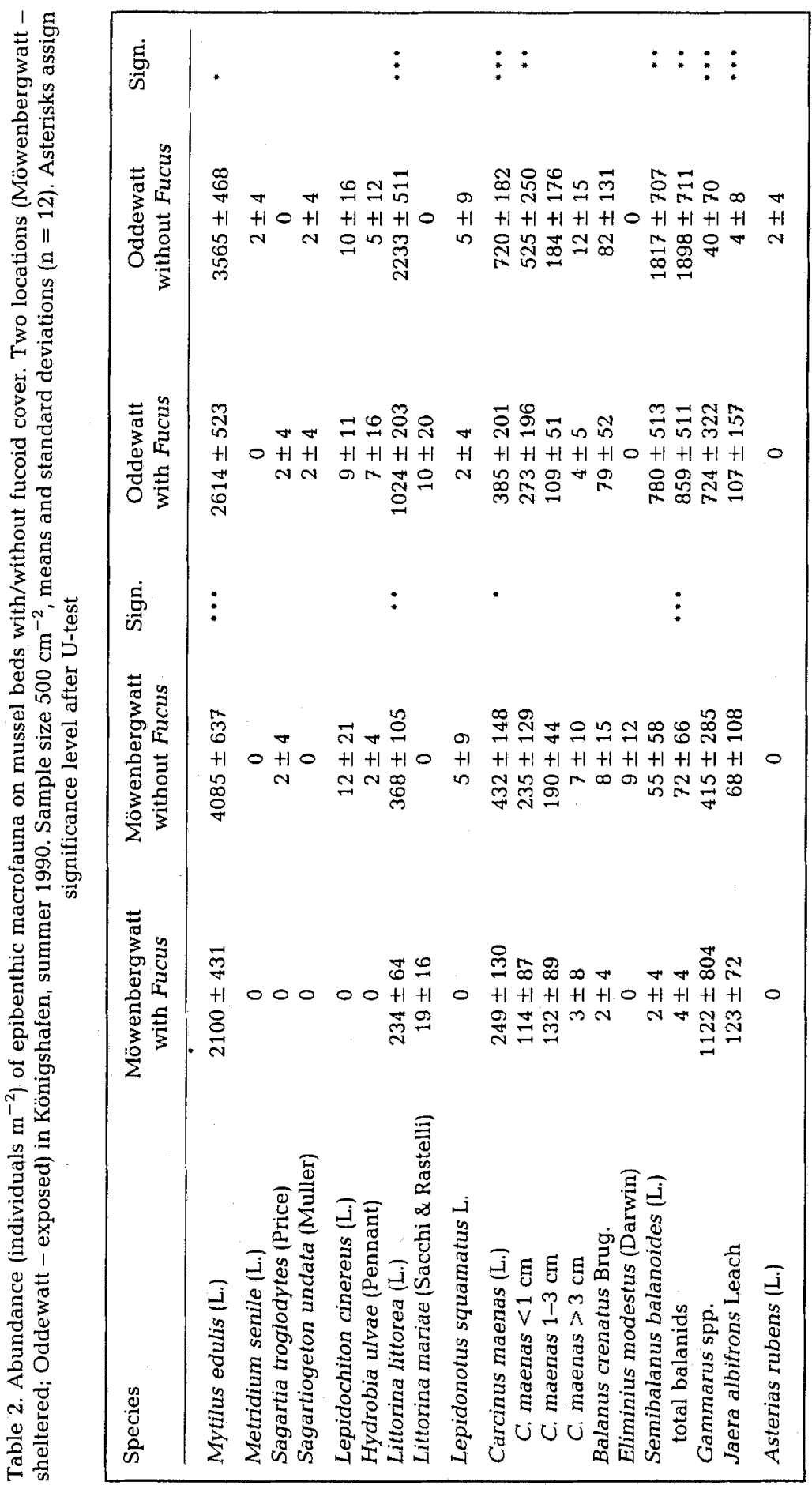




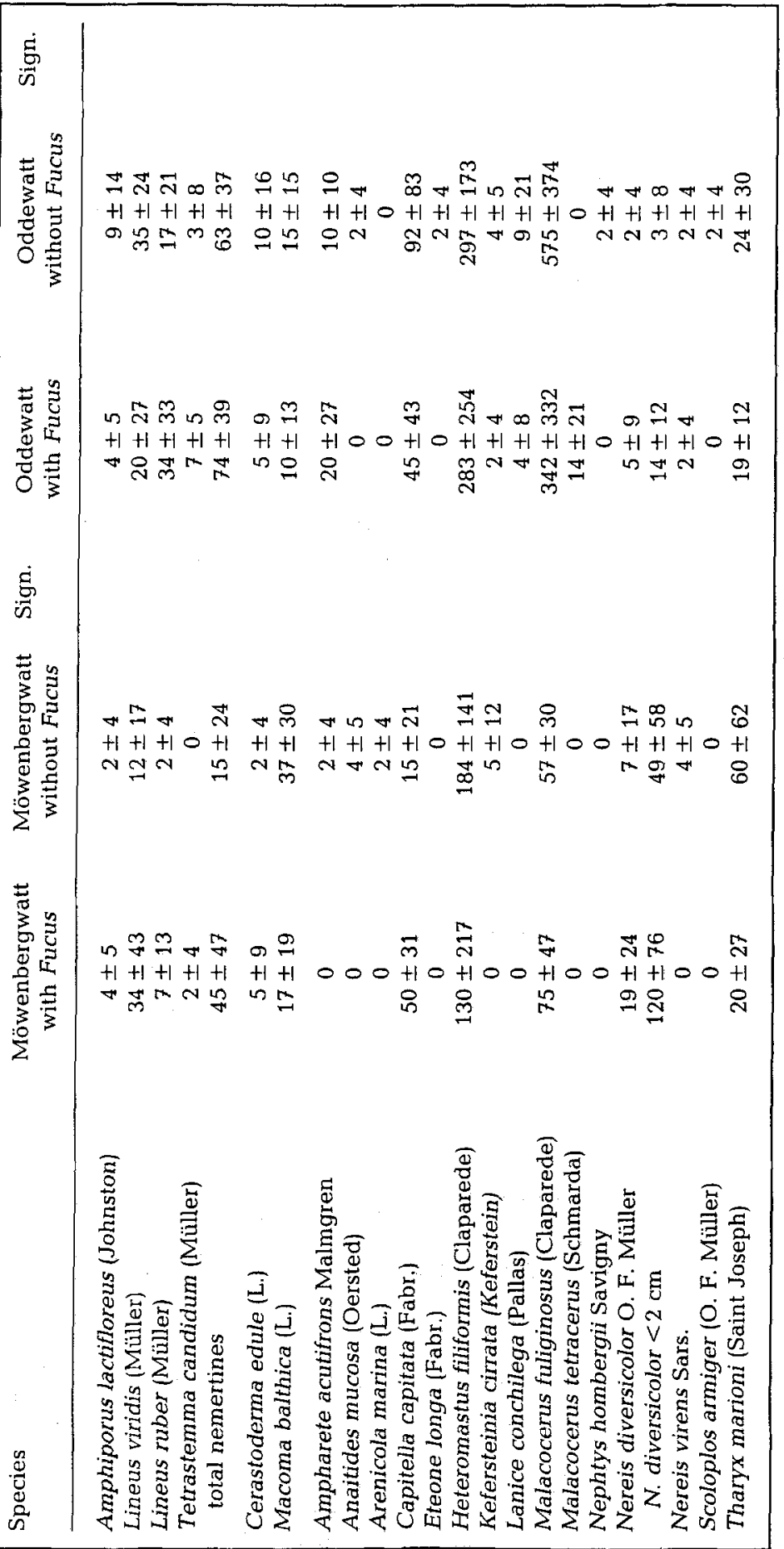


conspicuous differences with respect to infauna (Table 3). Total species number was always higher on bare mussel beds. Polychaetes, in particular, were less represented on Fucus-covered beds with regard to numbers of individuals. Abundances of several species (primarily epifauna) differed significantly in relation to algal cover (Fig. 2): mussels (Mytilus edulis), common periwinkles (Littorina littorea), shore crabs (Carcinus maenas) and barnacles (including Balanus crenatus, Elminius modestus and Semibalanus balanoides) were more abundant on uncovered mussel beds. For Carcinus maenas, this distribution was most pronounced in the O-group of crabs $(<1 \mathrm{~cm}$ carapace width).

The isopod Jaera albifrons and the flat periwinkle Littorina mariae attained higher densities on beds with fucoid cover, the latter occurring exclusively on plots with fucoids present. Differences between covered and uncovered beds were qualitatively the same at both investigation sites, but were reflected more clearly in the Oddewatt, which had a higher number of species as well as individuals. At this exposed site, a greater percentage of animals was found directly on the algae. The diversity index $\mathrm{H}$ was higher in the Oddewatt (1.86) than in the Möwenbergwatt (1.45). When comparing diversity and evenness on mussel beds with $(F)$ and without $(O) F$. vesiculosus, both parameters were higher on covered beds, regardless of location $\left(\mathrm{H}_{\mathrm{F}}=1.88 ; \mathrm{H}_{\mathrm{O}}=1.68\right.$ and $\mathrm{e}_{\mathrm{F}}=0.56 ; \mathrm{e}_{\mathrm{O}}=$ 0.48). The same holds true if the species using the macroalgae as habitat (mainly Littorina spp., Gammarus spp. and Jaera albifrons) are disregarded in the calculation, in order to assess their impact on diversity measures. In that case $\mathrm{H}_{F}=1.41$ as compared to $\mathrm{H}_{\mathrm{O}}=$ 1.34 , and $e_{F}=0.44$ as compared to $e_{O}=0.39$.

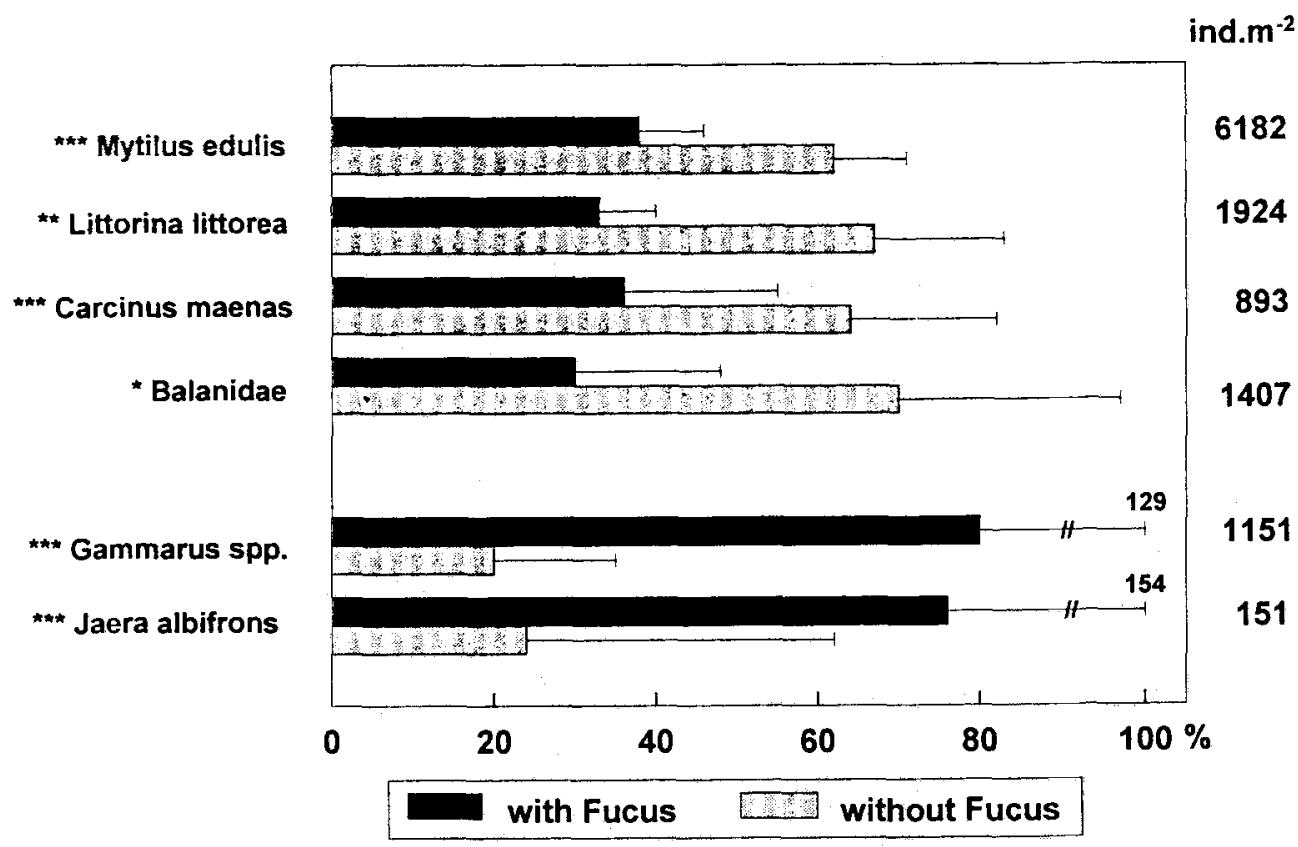

Fig. 2. Relative abundance of macro-epifauna, differing significantly on mussel beds with/without fucoid cover. Means and standard deviations $(n=24)$ and total numbers [individuals $\mathrm{m}^{-2}$ ] corresponding to $100 \%$. Königshafen, summer 1990 


\section{DISCUSSION}

All intertidal mussel beds in Königshafen are at least partly covered with Fucus vesiculosus. No growth has been reported on subtidal beds. In 1988, Parusel (1990) estimated $F$. vesiculosus surface cover in the Oddewatt to be $50 \%$. In 1990 and 1991 it was 60 and $95 \%$ and, at the second site, Möwenbergwatt, fucoid cover declined from 70 to $55 \%$. Thus, there is considerable interannual and intersite variation, but fucoids seem to have been present in the area always (see also Nienburg, 1927; Wohlenberg, 1937; Kornmann, 1952; Reise, 1977; Reise et al., 1989). By taking samples of benthic macrofauna selectively from partly algae-covered mussel beds, we could optimize the information gain in relation to sampling effort, which is particularly time-consuming in mussel beds. Also, it was possible to assess the effects of fucoid cover on mussel beds at different levels by comparing covered and uncovered plots (a) within single mussel beds, (b) of mussel beds at one location and (c) of all mussel beds independent of location. The following discussion will focus on algal-cover effects observed at both investigation sites, neglecting differences in species composition which are due to exposure or tidal level.

\section{Algal cover}

Our estimates of biomass refer to the above-ground thalli of $F$. vesiculosus. There is a considerable amount of thalli buried in mud. Judging from the dark colour and fragile nature, most of these thalli seem to consist of dead tissue. However, on resampling 6 clipped plots 33, and again 41 days later, a daily regrowth of about $4 \mathrm{~g}$ dry weight $\mathrm{m}^{-2}$ was calculated. Thus, what appears to be dead tissue showed a conspicuous potential for growth. Accordingly, our biomass figures were too low. At least part of the embedded thalli constitute viable biomass. With its high biomass and growth potential, $F$. vesiculosus represents an important factor on intertidal flats apart from its structural effects: with a total mussel bed area in Königshafen of $46000 \mathrm{~m}^{2}$ 'and an average $F$. vesiculosus cover of $70 \%$, the total dry weight of this macroalga in the bay amounts to $34000 \mathrm{~kg}$ or $19000 \mathrm{~kg}$ ash-free dry weight in summer.

\section{Mussel abundance}

The experimental mussel beds covered with $F$. vesiculosus lost about half of the mussels in the course of one year, and the mud surface intermittently increased by $30 \%$ of initial height. Without algal cover, only $15 \%$ of mussels were lost and the height of the mud surface decreased by $77 \%$ within one year. Presumably, deposition and erosion processes on mussel beds vary with weather conditions and depend on size, shape, and location of the beds. Our experimental set-up could not perfectly simulate natural deposition and erosion because artefacts were bound to be introduced by, for example, the comparatively small size of experimental mussel beds. However, the experiment demonstrates that algal cover affects sediment transport on mussel beds. It is suggested that the lower density of mussels underneath fucoids is, at least in part, caused by enhanced mud deposition. This interpretation is substantiated (1) by the observation that also on natural mussel beds, abundance is lower on overgrown patches compared to bare ones (see Table 2); and (2) by the predominantly endobenthic position of mussels covered 
by fucoids compared to epibenthic clumps and garlands in the absence of algae. We assume that mussels are suffocated by mud in the association with $F$. vesiculosus. This result is in fact the opposite of what Nienburg $(1925,1927)$ proposed, and constitutes a strong argument against his hypothesis of the Fucus-Mytilus assocation representing a mutual relationship.

Mussels are preyed upon by eiderducks (Somateria mollissima) as well as other birds (oyster catchers, Haematopus ostralegus, and herring gulls, Larus argentatus), which might respond negatively to the presence of fucoids. Ketzenberg (1990) observed feeding behaviour of these ducks, and found no difference in feeding activity on fucoid-covered and uncovered beds. Also, Albrecht (1991) compared length-frequency distributions of mussel populations on fucoid-covered mussel beds with those on uncovered sites, but reported no differences. If macroalgal cover significantly reduced predation (by birds as well as crabs), one would expect differing size spectra of mussels, because normally predation is selective for certain size groups. Thus, mussels do not seem to profit from reduced predation underneath fucoid cover.

\section{Structural influence of algal cover}

The algal cover may have beneficial effects by buffering heat stress, or as protection against desiccation during summer low tides. However, in the area of investigation this did not seem to be effective. The reduced abundance of barnacles is likely to be a consequence of the decrease in bare mussel surface area projecting into the water, and thus of the latter's decreased availability as substratum. Apart from that, the $F$. vesiculosus thalli which are moved back and forth by wave action may interfere with larval settlement and the development of barnacles, as has been described for rocky shores (Menge, 1976).

Several species seek shelter from predation under algal cover or in seagrass beds (Wilson et al., 1990). The same was expected for 'crabs, Carcinus maenas, in relation to fucoids, especially since the shore crab spends most of its juvenile lifetime in mussel beds (Ropes, 1968; Eriksson \& Edlund, 1977; Scherer \& Reise, 1981). On intertidal flats, mainly birds (gulls and oyster catcher - Zwarts, 1983) and fish (e.g. flounder - Jensen \& Jensen, $1985)$ prey on crabs, and it seems likely that $C$. maenas would hide under the dense cover of aigae to escape them. However, our results reveal the opposite, viz. the abundance of C. maenas was higher on mussel beds free of macroalgae. This refers particularly to small crabs, because juveniles $<10 \mathrm{~mm}$ carapace width comprised approximately $65 \%$ of the population in our study. It has to be mentioned that sampling at low tide does not always reflect conditions at high tide. During submersion, fucoid thalli project into the water column, leaving an accessible sediment surface underneath. On mussel beds without $F$. vesiculosus, where epibenthically growing mussels form a system of interstices between them, small crabs might in fact find better hiding places than under an algal vegetation where crevices and niches are mud-filled.

\section{Abundance of grazing herbivores}

The grazing species, Littorina mariae, Gammarus spp. and Jaera albifrons, were significantly more abundant on $F$. vesiculosus -covered mussel beds and were all at least 
partly found as epifauna directly on the algal thalli. Feeding on adult fucoids by herbivores was described for Littorina obtusata (van Dongen, 1956; Williams, 1990b), for the isopod Idothea baltica (Haahtela, 1984) or - under circumstances of temporal starvation - for Carcinus maenas (Janke, 1990). However, filamentous greens are generally preferred as food by grazers, when given the alternative to fucoids, because the latter succeed in deterring grazers by mechanical as well as chemical defense mechanisms (Nicotri, 1980; Watson \& Norton, 1985; Hay \& Fenical, 1988). Herbivore grazing on juvenile fucoids, which has been described for rocky shores (Lubchenko, 1983; Chapman, 1990; Janke, 1990), finds no parallel on intertidal sediments because there are no young fucoids present, as reproduction occurs solely vegetatively. The $F$. vesiculosus thalli in Königshafen showed grazing marks which have been observed to originate from Gammarus spp., but field- and laboratory experiments of Reise and Asmus \& Asmus (unpubl.) also demonstrated the preference of gammarids for filamentous green algal species. Haage (1975), Jansson \& Wulff (1977), Cattaneo (1983) and Williams (1990b) all mention the importance of epiphytic diatoms on fucoids for several grazing herbivores. However, the question as to what extent fucoids, on the one hand, and epiphytic microand macroalgae, on the other, contribute to the diet of the abundant grazing species is as yet unanswered and has to remain the subject of further investigations.

Higher percentages of grazing organisms found directly on the algae at our exposed study site might indicate the additional utilization of the thalli as habitat and for protection against mechanical stress, which becomes more pronounced the more exposed the location. Nicotri (1980) describes such varying significances of host algae as habitat and food source for epifaunal grazers. Also, reduced predation pressure of fish and shrimp on amphipods associated with macroalgae was documented by Nelson (1979) and Stoner $(1979,1980)$.

For Littorina mariae, the association with fucoids is imperative (Williams, 1990a; this study). Williams describes not only spatial but also temporal linkage of $L$. mariae to its host algae, in that the life history of the periwinkle is synchronized with that of the algae. He also mentions a particular bond of $L$. mariae to fucoids, because the snail deposits its egg masses on the algal thalli (in contrast to the common periwinkle, which deposits its eggs into the water). This was also observed in our study. The fact that Littorina littorea reached higher densities on mussel beds free of $F$. vesiculosus is surprising, when taking into account that food and feèding mechanisms are similar to Littorina mariae - in that diatoms as well as ephemeral or juvenile macroalgae are preferred foods (Lubchenko, 1978, 1983; Lein, 1980; Enright et al., 1983; Petraitis, 1983; Watson \& Norton, 1985; Imrie et al., 1990). However, the common periwinkle is known to graze on a broad range of surfaces, and in Königshafen it preferably associates with solid substrata (Wilhelmsen \& Reise, 1994). Because $L$. littorea is larger and its shell projects more from the surface than that of $L$. mariae, its presence on the algal thalli swaying with the waves and currents might be more difficult to maintain. Furthermore, the shading effects of fucoids may limit the growth of understorey algae (juvenile macroalgae and diatoms) and, thus, also the food supply for periwinkles on covered mussel beds (Chapman, 1990; Parusel, 1990).

We conclude that macroalgal cover with Fucus vesiculosus forma mytili on intertidal mussel beds changes the surface properties of the bed and therefore mainly affects associated species of epifauna. This holds true for sheltered as well as exposed locations, and thus for mussel beds with different physical and biological characteristis. Fucoids 
enhance sedimentation which leads to suffocation of part of the mussel population, causing the remaining individuals to grow mostly endobenthically. Therefore, the substratum area for epibionts, for instance barnacles, is reduced, and so is the interstitial space between mussels that is used by other community members as microhabitat. Secondly, fucoid cover serves - directly or indirectly - as food for herbivores. While direct consumption of $F$. vesiculosus appears to be less important, epiphytic growth of diatoms and filamentous green algae on $F$. vesiculosus-thalli provides food for several grazing species.

The macroalgal cover of mussel beds with $F$. vesiculosus partly increases habitat complexity through addition of a canopy structure, but, at the same time, reduces understorey habitat complexity by elimination of living space caused by sediment accumulation.

Macrobenthic endofauna is little influenced by fucoid cover on mussel beds, but overall macrobenthic diversity is increased.

Acknowledgements. We thank Dirk Schories who, during the summer of 1990, helped to collect the samples, and Elisabeth Herre who assisted with calculations and drawings during data analysis. The study was supported by the Federal Environmental Agency, the Environmental Natural Research Plan of the Minister for the Environment, Nature Conservation and Nuclear Safety of the Federal Republic of Germany (grant 10802 085/01) and the State of Schleswig-Holstein. This is publication no. 128 of the project "Ecosystem Research Wadden Sea".

\section{LITERATURE CITED}

Albrecht, A., 1991. Einfluß der Braunalge Fucus vesiculosus auf die Lebensgemeinschaft von Miesmuschelbänken im Wattenmeer. Dipl.Arb., Univ. Göttingen, 79 pp.

Asmus, H., 1987. Secondary production of an intertidal mussel bed community related to its storage and turnover compartments. - Mar. Ecol. Prog. Ser. 39, 251-266.

Asmus, H., Asmus, R. \& Reise, K., 1990. Exchange processes in an intertidal mussel bed: a Sylt-flume study in the Wadden Sea. - Ber. Biol. Anst. Helgoland 6, 1-79.

Austen, I., 1992. Geologisch-sedimentologische Kartierung des Königshafens (List/Sylt). - Meyniana $44,45-52$.

Cattaneo, A., 1983. Grazing on epiphytes. - Limnol. Oceanogr. 28, 124-132.

Chapman, A. R. O., 1990. Effects of grazing, canopy cover and substratum type on the abundances of common species of seaweeds inhabiting littoral fringe tide pools. - Botanica mar. 33, 319-326.

Dame, R. F. \& Dankers, N., 1988. Uptake and release of materials by a Wadden Sea mussel bed. - J. exp. mar. Biol. Ecol. 118, 207-216.

Dankers, N. \& Koelemaij, K., 1989. Variations in the mussel population of the Dutch Wadden Sea in relation to monitoring of other ecological parameters. - Helgoländer Meeresunters. 43, 529-535.

Dean, R. L. \& Connell, J. H., 1987. Marine invertebrates in an algal succession. III. Mechanisms linking habitat complexity with diversity. - J. exp. mar. Biol. Ecol. 109, 249-273.

Dittmann, S., 1990. Mussel beds - amensalism or amelioration for intertidal fauna? - Helgoländer Meeresunters. 44, 335-352.

Dongen, A. van, 1956. The preference of Littorina obtusata L. for Fucuceae. - Archs néerl. Zool. 11. 373-386.

Enright, C., Krailo, D., Staples, L., Smith, M., Vaughan, C., Ward, D., Gaul, P. \& Borgese, E., 1983. Biological control of fouling algae in oyster aquaculture. - J. Shellfish Res. 3, 41-44.

Eriksson, S. \& Edlund, A., 1977. On the ecological energetics of O-group Carcinus maenas (L.) from a shallow sandy bottom in Gullmar Fjord, Sweden. - J. exp. mar. Biol, Ecol. 30, 233-248.

Haage, P., 1975. Quantitative investigations of the Baltic Fucus belt macrofauna. 2. Quantitative seasonal fluctuations. - Contr. Askö Lab. Univ. Stockh. 9, 1-50. 
Haahtela, I., 1984. A hypothesis of the decline of the bladder wrack (Fucus vesiculosus L.) in SW Finland in 1975-1981. - Limnologica 15, 345-350.

Hay, M. E. \& Fenical, W., 1988. Marine plant-herbivore interactions: the ecology of chemical defense. - A. Rev. Ecol. Syst. 19, 111-145.

Hoek, C. van den, Admiraal, W., Colijn, F. \& Jonge, V. N. de, 1979. The role of algae and seagrasses in the ecosystem of the Wadden Sea. In: Flora and vegetation of the Wadden Sea. Ed. by W. J. Wolff. Balkema, Rotterdam, 9-118.

Imrie, D. W., McCrohan, C. R. \& Hawkins, S. J., 1990. Feeding behaviour in Littorina littorea: a study of the effects of ingestive conditioning and previous dietary history on food preference and rates of consumption. - Hydrobiologia 193, 191-198.

Janke, K., 1990. Biological interactions and their role in community structure in the rocky intertidal of Helgoland (German Bight, North Sea). - Helgoländer Meeresunters, 44, 219-263.

Jansson, A. M. \& Wulff, F., 1977. Ecosystem analysis of a shallow sound in the northern Baltic - a joint study by the Askö Group. - Contr. Askö Lab. Univ. Stockh. 18, 1-160.

Jensen, K. T. \& Jensen, J. N., 1985. The importance of some epibenthic predators on the density of juvenile benthic macrofauna in the Danish Wadden Sea. - J. exp. mar. Biol. Ecol. 89, 157-174.

Kangas, P., Autio, H., Hälfors, G., Luther, H., Niemi, A. \& Salemaa, H., 1982. A general model of the decline of Fucus vesiculosus at Tvärmine, south coast of Finland, in 1977-1988. - Acta bot. fenn. $118,1-27$.

Ketzenberg, C., 1991. Nahrungsökologie der Eiderernte (Somateria mollissima) im Königshafen bei List/Sylt. Dipl.Arb., Univ. Kiel, $91 \mathrm{pp}$.

Kornmann, P., 1952. Die Algenvegetation von List auf Sylt. - Helgoländer wiss. Meeresunters. 4, $55-61$

Lein, T. E., 1980. The effects of Littorina littorea L. (Gastropoda) grazing on littoral green algae in the inner Oslo-Fjord, Norway. - Sarsia 65, 87-92.

Lubchenko, J., 1978. Plant species diversity in a marine intertidal community: importance of herbivore food preferences and algal competitive abilities. - Am. Nat. 112, 23-29.

Iubchenko, J., 1983. Littorina and Fucus: effects of herbivores, substratum heterogeneity, and plant escapes during succession. - Ecology 64, 1116-1123.

Menge, B. A., 1976. Organization of the New England rocky intertidal community: role of predation, competition, and environmental heterogeneity. - Ecol. Monogr. 46, 355-393.

Nelson, W. G., 1979. Experimental studies of selective predation on amphipods: consequences for amphipod distribution and abundance. - J. exp. mar. Biol. Ecol. 38, 225-245.

Nicotri, M. E., 1980. Factors involved in herbivore food preference. - J. exp. mar. Biol. Ecol. 42, 13-26.

Nienburg, W., 1925. Eine eigenartige Lebensgemeinschaft zwischen Fucus und Mytilus. - Ber. dt. bot. Ges. 43, 292-298.

Nienburg, W., 1927. Zur Ökologie der Flora des Wattenmeeres. I. Der Königshafen bei List auf Sylt. - Wiss. Meeresunters. (Kiel) 20, 146-196.

Nienhuis, P. H., 1970. The benthic algal communities of flats and salt marshes in the Grevelingen, a sea arm in the south-western Netherlands, - Neth. J. Sea Res. 5, 20-49.

Obert, B. \& Michaelis, H., 1991. History and ecology of the mussel beds (Mytilus edulis L.) in the catchment area of a Wadden Sea tidal inlet. In: Estuaries and coasts: spatial and temporal intercomparisons. Ed. by M. Elliott \& J.-P. Ducrotoy. Olsen \& Olsen, Fredensborg, 185-194.

Parusel, E., 1990. Die Bedeutung der Braunalge Fucus vesiculosus forma mytili (Nienburg) Nienhuis für den Nährstoffumsatz einer "Fucus-Mytilus-Bank" unter besonderer Berücksichtigung der Nährstoffversorgung der Algen. Dipl.Arb., Univ. Bremen, 104 pp.

Petraitis, P. S., 1983. Grazing patterns of the periwinkle and their effect on sessile intertidal organisms. - Ecology 64, 522-533.

Reise, K., 1977. Predator exclusion experiments in an intertidal mud flat. - Helgoländer wiss. Meeresunters. 30, 263-271.

Reise, K., Herre, E. \& Sturm, M., 1989. Historical changes in the benthos of the Wadden Sea around the island of Sylt in the North Sea. - Helgoländer Meeresunters. 43, 417-433.

Riesen, W. \& Reise, K., 1982. Macrobenthos of the subtidal Wadden Sea: revisited after 55 years. Helgoländer Meeresunters. 35, 409-423. 
Ropes, J. W., 1968. The feeding habits of the green crab, Carcinus maenas (L.). - Fish. Bull. 67, 183-203.

Sachs, L., 1984. Angewandte Statistik. Springer, Berlin, 552 pp.

Scherer, B. \& Reise, K., 1981. Significant predation on micro- and macrobenthos by the crab Carcinus maenas L. in the Wadden Sea. - Kiel. Meeresforsch. (Sonderh.) 5, 490-500.

Stoner, A. W., 1979. Species-specific predation on amphipod crustacea by the pinfish Lagodon rhomboides: mediation by macrophyte standing crop. - Mar. Biol. 55, 201-207.

Stoner, A. W., 1980. Abundance, reproductive seasonality and habitat preferences of amphipod crustaceans in seagrass meadows of Apalachee Bay, Florida. - Contr. mar. Sci. 23, 63-67.

Swennen, C., Nehls, G. \& Laursen, K., 1989. Numbers and distribution of eiders Somateria mollissima in the Wadden Sea. - Neth. J. Sea Res. 24, 83-92.

Verwey, J., 1954. On the ecology of distribution of cockle and mussel in the Dutch Wadden Sea, their role in sedimentation and the source of their food supply. - Archs. néerl. Zool. 10, 171-239.

Watson, D. C. \& Norton, T. A., 1985. Dietary preferences of the common periwinkle, Littorina littorea (L.). - J. exp. mar. Biol. Ecol. 88, 193-211.

Wilhelmsen, U. \& Reise, K., 1994. Grazing on green algae by the periwinkle Littorina littorea in the Wadden Sea. - Helgoländer Meeresunters. 48, 233-242.

Williams, G. A., 1990a. Littorina mariae - a factor structuring low shore communities? - Hydrobiologia $193,139-146$.

Williams, G. A., 1990b. The comparative ecology of the flat periwinkles Littorina obtusata (L.) and Littorina mariae Sacchi et Rastelli. - Fld Stud. 7, 469-482.

Wilson, K., Able, K. W. \& Heck, K. L., 1990. Predation rates on juvenile blue crabs in estuarine nursery habitats: evidence for the importance of macroalgae (Ulva lactuca). - Mar. Ecol. Prog. Ser. 58, 243-251.

Wohlenberg, E., 1937. Die Wattenmeer-Lebensgemeinschaft im Königshafen von Sylt. - Helgoländer wiss. Meeresunters. 1, 1-92.

Ziegelmeier, E., 1964. Einwirkungen des kalten Winters 1962/63 auf das Makrobenthos im Ostteil der Deutschen Bucht. - Helgoländer wiss. Meeresunters. 10, 276-282.

Ziegelmeier, E., 1970. Über Massenvorkommen verschiedener makrobenthaler Wirbelloser während der Wiederbesiedlungsphase nach Schädigung durch "katastrophale" Umwelteinflüsse. - Helgoländer wiss. Meeresunters. 21, 9-20.

Zwarts, L., 1983. Habitat selection and competition in wading birds. In: Ecology of the Wadden Sea. Ed. by W. J. Wolff. Balkema, Rotterdam, 6, 271-279. 